DOI: 10.2478 /ausp-2020-0023

\title{
V. Voiculescu's Novel: A Modern Depository of the Traditional Beliefs
}

\author{
Sorin Gheorghe SUCIU \\ Department of Applied Linguistics \\ Sapientia Hungarian University of Transylvania (Cluj-Napoca, Romania) \\ Faculty of Technical and Human Sciences \\ suciu.sorin@ms.sapientia.ro
}

\begin{abstract}
Part of a larger research, initially thought and written as an essay, our paper is a transdisciplinary approach on Elmar Salmann's idea of the novel as the modern depository of humanity's religious and philosophical legacy, which would otherwise not find a way to express itself nowadays. As a support, we are using the one and only novel of a profound religious Romanian writer - V. Voiculescu's Zahei Orbul (Zahei the Blind) -, trying to reveal Jean-Luc Marion's concept of “distance” but also Milan Kundera's view regarding the matter as it is discussed in The Art of the Novel. As stated before, in our deductive approach, we are using Basarab Nicolesco's "the hidden third", the basic concept in transdisciplinary research. Our conclusion is that Voiculescu's novel is constructed on the grounds of God's "absence", as He retreats in the "distance". This "absence" is supported by a net of Christian symbols on which the modern world's elements are being interwoven in Midrash style, as Constantin Jinga states.
\end{abstract}

Keywords: culture, novel, transdisciplinarity, philosophy, theology

\section{Introduction and literature review}

Starting from Milan Kundera's thought about “the novel's wisdom” (2008), this paper tries to present Vasile Voiculescu's narrative, Zahei Orbul (Zahei the Blind), through Elmar Salmann's (2010) thought regarding the novel as a modern depository of the traditional culture, as it was seen by Nikolai Berdiaev. ${ }^{1}$ The attempt to answer the question, which is the starting-point of this endeavour, namely Voiculescu's reason for

1 "The culture - says Nikolai Berdiaev - is related to the cult; it develops starting from the religious cult; it is the result of the cult's extension and differentiation. The philosophical thinking, scientific knowledge, architecture, sculpture, music, and ethics are being organically and entirely contained by the Church's cult, in an indistinct form. The culture is related to the tradition and the ancestor's cult. It is filled with sacred symbolism; it bears within the signs and images of a spiritual reality" (Berdiaev apud Crainic 1929: 8). The translations of the citations from the works in Romanian in this paper are ours. 
writing a novel (with a possible "answer” offered by Kundera's thought), represents the pretext for our effort in revealing the fact that Voiculescu's novel intertwines on a canvas of Christian symbols which are trying to sustain a transcendental silence, an "absence" of God shouting from the picture of the singular novel of an author who was a true believer. If God is Love, then blocking Zahei's access to it, being it eros - even if knowledge through eros is allowed up to a point - or agapé, is the way in which the author suggests the failure of a world torn apart from the simple and ultimate authenticity of the human soul. In order to achieve this goal, we are using Salmann's ${ }^{2}$ view regarding the fact that the novel as a literary genre is the modern depositary of the religious belief which is absent from our modern secular society. Actually, this idea of literature as a meaning to escape from the profane time into the sacred - an acute necessity for man throughout the centuries, which became chronic nowadays - is not new, being also underlined by Mircea Eliade in The Sacred and the Profane. ${ }^{3}$ Adding to that, even Voiculescu's style of making literature, revealed, amongst others, by Constantin Jinga (2001), should support our attempt to present the net of Christian symbols emerging from his novel and supporting the frame of a theological and philosophical structure which is, in fact, the novel itself.

Therefore, here are Kundera's words:

The novelist is no one's spokesman and I would like to push this statement to the limit, saying that he is not even the spokesman of his own ideas. When Tolstoi laid out Anna Karenina's first version, Anna was a very unpleasant woman and her tragic end was perfectly just. The final version is entirely different but I do not think that Tolstoi changed his ethical grounds in the meantime, I would rather say that he was not listening to his own moral voice but to another one's. He was listening to something I would like to name as the

2 "The novel (...) is the mirror and, probably, the most accurate reflection of the modern subject's birth and decay, thus ours too. We could say that the novel is even more skilful than Kant because it abandons itself to the open game between destiny and freedom, between the observer and the observed world. Thus, in its complexity, it tends to playfully substitute the religion. The novel is the modernity's small sacrament in which we are reflecting, understanding, losing, and finding ourselves again. It is an entire universe, from certain perspectives, even more brilliant than the philosophies. And, naturally, we should ask ourselves the question: what is the rapport between this immense archipelago of the modern novel and Christianity" (Salmann 2010: 180).

"But in comparison with the religious man, there is an essential difference. The latter experiences intervals of time that are «sacred», that have no part in the temporal duration that precedes and follows them, that have a wholly different structure and origin, for they are of a primordial time, sanctified by the gods and capable of being made present by the festival. His trans-human quality of liturgical time is inaccessible to a nonreligious man. This is as much as to say that, for him, time can present neither break nor mystery; for him, time constitutes man's deepest existential dimension; it is linked to his own life, hence it has a beginning and an end, which is death, the annihilation of his life. However, the temporal rhythms that he experiences, however great their differences in intensity, nonreligious man knows that they always represent a human experience, in which there is no room for any divine presence" (Eliade 1961: 57). 
novel's wisdom (...). But what is this wisdom, what is the novel? There is an admirable Jewish proverb: The man thinks, God laughs (...). I like to believe that the art of the novel came onto earth as an echo to God's laughing. But why is God laughing looking at the man thinking? Because the man thinks and the truth is slipping away. Because one's thinking is departing further and further from another's as they are struggling to do even more thinking. And, finally, because the man is never what he thinks he is. (Kundera 2008: 194-195)

Thinking, but not too hard because we do not want to provoke God's death by laughing, after Nietzsche declared Him dead already, we are trying not to silence the $d y b u c$ ' $^{4}{ }^{4}$ voice in order to make our endeavour an authentic one and to avoid the danger of joining the ranks of the agelasts. ${ }^{5}$ Therefore, following the logic of the starting-point, ${ }^{6}$ it would be good if we could reject the rational thinking - actually the rationalistic thought -, making thus an attempt at the possibility of having a glimpse of what Grace working together with Voiculescu's writing hand wanted to reveal through his novel. Or, even better, trying (as many others did it before us) to reconcile the learning through spirituality, through love, with the rational understanding, which would not be an attempt to provoke God's death by laughing, hypothetically, of course, but would help us achieve a higher level, closer to His love; in other words, to descend our mind into our heart. This would be a flight into the light of agapè, a flight initiated by the rush of an eros cooled off by a healthy

$4 \quad$ Regarding the aforementioned proverb, we mention the fact that in Jewish folklore the dybuck represents the dislocated soul of a deceased person, a spirit evaded from Gehenna (the Hebrew equivalent of Christianity's Hell, or Greek's Hades). The word dybuck can be translated through the English meanings of locking and addition contained by the word attachment. According to Jewish traditional belief, the dybuck is the spirit of a person who did not fulfil his/her purpose in his/her lifetime. It gets the green light for fulfilling its duty under this form, as an attached spirit to a living person, getting, mostly, help from this living person. The term is being used here to define the Other (being it, from everyone's perspective, the voice of Plato's daimon guiding the artist's creation, Jung's collective unconscious, for example, or even God's Grace). The dybuck abandons the "host" when its mission is accomplished.

5 “(...) the word comes from Greek and its meaning is: the one who does not laugh, who does not have any sense of humour. Rabelais hated the agelasts. He was afraid of them. He was complaining that the agelasts were «so badly against him» that at one point he even considered to quit writing. Peace is not possible between the novelist and the agelasts. Because they have never heard God's laugh, the agelasts are sure that all humans should think the same way as they do and that they really are what they think they are" (Kundera 2008: 195-196). If it is to make a parallel, the agelast is the equivalent of Fondane's schizophrenic human type, which is portrayed through the perceptions of an old man suffering from this mental illness, cited by Roger Caillois in the epigraph to his Le Procès Intellectuel de l'Art: "Look at those roses, my wife would have found them beautiful; to me they are nothing more than a bunch of leaves, petals, horns, and stems" (Caillois apud Fundoianu 1980: 609). The schizophrenic type of human "is that who hates and finds existence repulsive, relentlessly persecuting it in the name of a thinking named Esprit, a thinking emptied of any trace of sensible core - an intellectual type so widespread nowadays that one could think that it was created by our epoch itself" (Fundoianu 1980: 611). That of God's laughing seen as intentio operis. 
reason. At the same time, the cold reason's excesses - born from Lucifer's ego would have been adjusted by our generous heart. ${ }^{7}$

Going forward and using the title of the introductory study to the last edition of Voiculescu's novel (Sorescu in Voiculescu 2010: 10), we are recalling to Rudolf Steiner's writings about the initiation in Greece's antiquity mysteries, where the author reveals the fact that the commoner, living in some kind of blessed darkness, cannot and should not be taken away from a state of relative happiness which he/ she enjoys. If the mystic revealed his knowledge to those who are not initiated, as Steiner believes that it happened in Aeschylus's case, ${ }^{8}$ they would only have some plain words to work with, words which could not affect their sensory lives.

Without these (a hard initiation, italics ours, SGS), the hearer would have been flung into emptiness, into nothingness. He would have been deprived of what gave him happiness without being able to receive anything in exchange. It might be said that one could not have taken anything from him. For certainly mere words could not change his life of experience. He could only have experienced reality through the objects of his senses. One could have given him nothing but a dreadful, life-destroying apprehension. This could be regarded as a crime. The above is no longer fully valid today for the acquisition of spiritual cognition. The latter can be understood conceptually because modern man has a capacity to form concepts which the ancients lacked. Today, people can be found who have cognition of the spiritual world through their own experience; they can be confronted by others who comprehend these experiences conceptually. Such a capacity for forming concepts was lacking in the ancients. (Steiner 1961: 12)

Steiner's approach, more of a wishful thinking, in our opinion, tries to find a timid escape from the law of non-contradiction and proposes a dialogue to reconcile two antagonistic ways of thinking in order to re-create, in ourselves, the unity of being. Nietzsche did the same thing with his Übermensch, which was tainted by Nazi propaganda. The Greek ancient tragedy was, in Nietzsche's view, the only form of art which succeeded in expressing the Dionysian through the Apollonian, making peace between the two opposite sides of the existence. The Dionysian element was to be found in the music performed by the ancient choir and the Apollonian in the dialogue following it, dialogue which presented a concrete symbolism as an equalizer for the Dionysian reverie. But both of them are outside the revealed Truth, as Marion (2007: 55-125) showed in Nietzsche's case. Despite their efforts - or

$7 \quad$ A sin confessed by Voiculescu.

8 Steiner writes that, even if he was not a mystic, Aeschylus revealed in his works some of the existence's secrets. His superior intellect was capable, in Steiner's opinion, to reach and grasp the forbidden knowledge, thus being forced to find refuge in the temple of Dionysus just to avoid being murdered as a "traitor". 
maybe just because of that -, both are still walking on the idolatry's territory. Trying the theosophical way - which became anthroposophical later, after he gave up on Theosophical Society -, Steiner is still camped in the zone of conceptual idolatry.

On the other hand, Nietzsche himself was defeated by Ananké, as underlines Fondane, a triple alienated ${ }^{9}$ who, walking on Chestov's footsteps, fights with the philosopher's "unfertile" thought, proposing an existential thought where poetry would be the link between human's antagonistic dimensions. A mystic himself, as Voiculescu was, Fondane tried to combine in his writings the mystical way of thinking with the dialectic and with poetry as well. And both had the "privilege" to experience the mystical bliss on the verge of extinction, one at Birkenau and the other at Jilava and Aiud. Fondane argues Plato as a representative of the rational thought in open conflict with the poetical thinking. Plato tried to correct his predecessors' immoral excesses and saw the poet's inspiration as the corybantic delirium of those who were incapable of dancing without getting out of their minds. To Plato, the poet was "driven by a divine power", "out of his mind", "irresponsible", "possessed", characteristics which are contained in Rimbaud's expression: "I is another". Plato's thought won, Poetry being banished from the City. But its charm survived, reminding us of another truth, a truth which:

transcends the intellectual act and the moral purity, a truth to whom the existence exists, as the physical body exists and as the images are, to whom God Himself is image, vision, and not a pure act of thinking coming from an empty mind... This "charm" does not want to shrink more the "shortage of reality", which is the dialectics' heritage; it does not want to humiliate the reality of an absolute of the thought thinking itself but to find a way in which we could get rid of this reality's imperfections and bring it, by broadening it up to its fulfilment, curing it from the wound and corruption suffered on the part of ethical and speculative thought. These remains of the thought filtered through the language and surviving in the poem even after the gods "abducted the poet's intelligence", precisely these remains are to be censored from the poem by the poet in order to allow inspiration paramount and to let in only the pure gods' voice. "I is another". The one who retouches the poem is also the Other; and what is eliminated from it is again and always the Ego. (Fundoianu 1980: 667)

Voiculescu's novel, as a work of art, represents the profane way through which the sacred truth, enclosed in symbols, struggles to emerge into the light in a world where the sacred tries to find new forms for itself. The author of the "intentio operis" concept seems to complete the previous sentence:

9 Benjamin Wexler/B. Fundoianu/B. Fondane: Jew amongst Romanians, Jewish poet amongst the Jewish (and on top of that "an anarchist in the synagogue", as it was described by Radu Cernatescu) and Romanian poet of Jewish origin amongst the French. 
The gods speak (today we would say: Being is speaking), through hieroglyphic and enigmatic messages. [...] Truth is something we have been living with from the beginning of time, except that we have forgotten it. If we have forgotten it, then someone must have saved it for us and it must be someone whose words we are no longer capable of understanding. So this knowledge must be exotic. Carl Jung has explained how it is that once any divine image has become too familiar to us and has lost its mystery, we then need to turn to images of other civilizations, because only exotic symbols are capable of maintaining an 'aura' of sacredness. (Eco 1992: 150)

One of the symbols used by Voiculescu in his novel's core is that of the blind man guided by a cripple, a symbol which is supposed to be borrowed from the Hindu folklore. ${ }^{10}$

\section{Research methodology}

As stated in the Abstract, this paper was initially thought and written in a form of an essay and adapted to better meet the requirements of an academic work. Therefore, we are using, initially, the deductive method inferring from some concepts regarding the subject of the novel as being the modern depository of the religious and philosophical beliefs.

At the same time, we are trying to use Nicolesco's "the included middle", the basic concept of transdisciplinarity, ${ }^{11}$ a concept developed from the field of quantum physics and on the footsteps of three Romanian philosophers, Stephane Lupasco, Emil Cioran, and B. Fondane. This method can also be imagined through Marion's view on the concept of distance: "[...] the distance opens the unifying departure only starting from a term which is revealing inside it, or, better said, which discovers in itself its own horizon: the distance reveals only as a road that is being cleared, starting from a place, and not as the itinerary is read on a map, from the elsewhere

10 "The image appears in Sāmkhya kārikā (attributed to Īshvarakrshna), and it is further developed in Gaudapāda's (Gaudapādabhaāshya) mediaeval commentary, to explain through suggestion the union between the inactive and insulated Spirit (purusha), seen as a cripple (pangu; pangu is also the name of planet Saturn, «the cripple» from the alchemy's illustrations) and primordial and un-manifested (avyakta) Nature (praktri) compared to a blind (andhā). These two make a unique and a whole creature: pangvandhavān, a «cripple and blind». I do not know if the image existed before the Hindu folklore or entered it as a consequence of this text" (Culianu 2000: 20).

11 Trying to draw a bridge between science and ontology and using Galilei's axioms as a model, Nicolesco elaborates the axioms of transdisciplinarity: "i. The ontological axiom: There are, in Nature and in our knowledge of Nature, different levels of Reality and, correspondingly, different levels of perception. ii. The logical axiom: The passage from one level of Reality to another is insured by the logic of the included middle. iii. The complexity axiom: The structure of the totality of levels of Reality or perception is a complex structure: every level is what it is because all the levels exist at the same time" (Nicolesco 2006: 150). 
of a neutralized representation" (2007: 278). The "included middle" or "the hidden third" is the fundament of Nicolesco's second axiom of transdisciplinarity, the logical axiom, as opposed to the classical principle of the excluded middle, the equivalent of the law of non-contradiction, the very base of scientism.

Another aspect of our paper is the fact that we are using long citations. This is not because of our lack of skills in rephrasing and discussing the topic but because we think that the ideas of the authors themselves should be highlighted. In our opinion, a larger context of an idea, as it was initially thought, should be made available for the readers. Therefore, our way of writing is somehow similar to Marion's method, mentioned before, trying to clear a path through the thick woods from a "place" which is revealing itself in the "distance", following the steps of the Son as He retreats onto the Father being replaced by God's Grace, as the "hidden third", which keeps all the things together in the world, on our level of Reality. In other words, our road is constructing itself under our feet, as we put one foot before the other walking towards our goal, which may never reveal itself completely, at least not objectively.

\section{Discussion}

\subsection{Short interlude}

As an intermediary step, we mention Capul de zimbru (The Bison's Head), Voiculescu's testament-short story, ${ }^{12}$ the only text published by him after 1945 . The clash of two symbols, two pieces of an extremely rare stamp - "bison head" -, with different meanings for each of the possessors, becomes an opportunity for the hero to make a symbolic exit from the world which begins to fade under the red shadow coming from the Eastern star. In the middle of the Ukrainian steppe - where a handful of Romanian soldiers (living in a "terror emerging from the inner cosmos") have the occasion to defy any theoretical approach on existentialism made by the philosophers from their comfortable armchairs -, two ways of understanding the world are colliding. The one who loses the battle takes the road of fire, as it was tainted by the modern world's mercantile spirit. 'And now, please forgive me, general, for this disappointment and allow me to get out. I feel the need to make contact with the bleakness. It is noble, unlike us.' "And, standing up in order to walk towards the door, captain Tomuț slowly made a turn, reaching the stove where he threw the bison's head into the burning ember shouting: 'Tertium non datur'. No one was surprised" (Voiculescu 2003: 105).

12 An interesting analysis made by Roxana Sorescu compares Lucian Pintilie's motion picture, Tertium non datur, with its source of inspiration, Voiculescu's short story, to reveal one of the author's options, that of plunging into the flame of "The Burning Bush" in order to save his identity (Sorescu 2006). 
And this is how the author - who would complete his life's work by adding writings worth reaching universality - tried to disappear into the flames of "The Burning Bush". ${ }^{13}$ The longest of them, Zahei Orbul, will become something more than the author initially wanted, in the spirit of that "wisdom of the novel" as an "echo to God's laugh" theorized by Kundera and this paper's point of origin. Not allowing the spark which could start love's fire into the heart of the hero with a physique reminding of the ancient gods, but unaware of the dormant sacredness lying deep inside his being, Voiculescu reveals to us, through absence, the only way in which the modern world could be saved before The Judgment Day. Love, from which "by giving you will earn" (Steinhardt, 1994). Slim chances for our hero, a presumed tragic figure ${ }^{14}$ resembling Philoctetes and Job. And this is probably the reason why Sorescu writes that: "Zahei Orbul is the most hopeless symbolic narrative in the Romanian literature. The counterpart cannot be other than the most optimistic one, the story of the woman who restores the order into the world by making her own justice. Vitoria Lipan, as well as an essence of an archaic symbolic civilization, represents the antonymous type to Zahei. She wins in immanence just as Zahei fails in transcendence" (Sorescu in Voiculescu 2010: 48). Commenting on Sorescu's words, we could say that Vitoria wins in immanence because she knows what she wants and wants what is right, and thus the transcendence guides her into the right direction. Her access to the other world is not being cut by an author who was not a believer but wrote by inspiration. On the other side, Zahei - being basically a good man even when he tumbles down on the vices' slope - does not have the chance to know the laws of a traditional archaic society as Vitoria did. Vitoria's itinerary can be traced through the traditions of a multimillenary world. She begins her quest with the entire nature alongside, as nature itself needs to restore its unbalanced order. Even more, the transcendent, through Saint Anna, watches the fiery woman's way, protecting and guiding her in the key moments. Sadoveanu's main character is not a Christian figure, her spirit being in tune with the Old Testament's Law of the Talon. And, paramount argument, she is driven by love, the love for her husband given by God. On the other hand, Zahei's itinerary begins with his "gift" of blindness as a means to salvation. But his innate good nature and righteousness are not enough to compensate the absence of a spiritual mentor. Being denied even the chance of the healing power of a mother's love, Voiculescu's character reveals the failure of the author's belief, as one could see it from his early

13 We are talking here about the group formed at the Antim monastery in Bucharest, a group which gave Voiculescu the opportunity to be initiated in the hesychast way of living, as it is pointed out by Valeriu Anania: "Through these meetings, he begins to learn and deepen his knowledge in the Philokalia and makes Hesychasm not just a study object but a universe of a spiritual endeavour with spectacular benefits for his poetry [...]. The poems which fully represent the great religious poet V. Voiculescu were written between 1949 and 1958. They were published, partially, in 1983, conventionally entitled Clepsidra (The Hourglass)" (Anania 1995: 165).

14 Presumed because there is no tragic for a true believer, as there is no fracture either. Job does not lose his faith in God even if he curses and yells his pain asking Him to explain his unjust suffering. 
poetry: "My own sack of clay to liven up (...)/ And, clashing to myself, forever/ I tried to be a strike of light". The vision about the failure of the Luciferian attempt to reach the Light exclusively through one's own efforts, without "qualified" guidance/ initiation, could have been ignited by the providential meeting with father John the Foreigner (Ivan Kulighin) and his teachings at the Antim monastery - a sanctuary for the spiritual effervescence emanated from the cooperation between a significant part of Romania's élite, retreated from the path of the communist bulldozer, and monks living according to Christ's law, theologians in the true meaning of the word.

\subsection{A failed initiation}

Coming back to Steiner's thought continued towards the initiation in the mysteries of the "Burning Bush" movement, we can point out the fact that the character of Voiculescu's novel is being "blessed" with blindness (by demiurge author's will) through a venal Greek innkeeper from the cosmopolitan port of Brăila. He has now all the "qualities" needed for finding the true Light. What is missing, however, is an authentic spiritual father who could guide his footsteps into the Light. In our opinion, this is the main reason why his initiation path is actually a dead end. André Scrima reveals the source of this basic tradition of the Eastern Christian belief, which represents the Church's "mystical pilgrimage" instituted on the place of the extinct Roman Empire. "Essential word (we would be tempted to say 'sovereign') of the orthodox spirituality, the notion of spiritual Father has all of the characteristics of a nodal value. No definition could contain it, not to mention about exhausting it" (Scrima 1996: 183). Underlining the emergence of "the new kind of hermits" (a collocation made by Saint John Cassian) into the world starting with the Desert Fathers from the $4^{\text {th }}$ century B.C., Scrima writes that this tradition does not try to contest or double the Church but has the purpose to perpetuate inside it a:

mutation with the spiritual Father as its archetype. A mutation which should be named «spiritual» (pneumatic), even with the risk of being tautological: The spiritual Father is, firstly, the man who became pneumatic himself, in the most realistic meaning of the term - that of the Holy Spirit emerging, at a unique height, from Christ's body, dead and resurrected. We have here an ultimate «reference» on which no image or conceptual translation could be possible to infer as any of them being instantly burned by the proximity of this «advent». It is a reference which signifies - in the Son's 'obliteration' through kenosis (cf. Philippians 2, 7) and in the Father's «retreat» through distance (“... why have you forsaken me?") - a new manifestation of Trinity, the manifestation of the Holy Spirit as 'hidden' of their relationship: the Holy Spirit himself is the one who touches, from now on, the man, as principle of a transfigured knowledge and as possibility of a new, "liberated" life. (ibid.: 184) 
Therefore, observing what kind of priests would have had the possibility to guide Zahei into finding the Light - even if our blind character seeks its physical side, the chance to see again with his clay eyes, not noticing that he is very close to the true sight -, one can feel that the contrast between their "qualities" and the indispensable grace needed for that endeavour becomes unbearable. Father Gioarsă, ${ }^{15}$ if it is to recall them chronologically, defiles his kin by being at the same time beggars' master, trader of stolen goods, and, on top of that, old flirt trying to seduce young gipsy females. He tries to steal Panther's "golden mine", ${ }^{16}$ the only way in which the degenerate priest sees Zahei. The biggest "achievement" of the second "God's servant", father Țurcă, nicknamed Burtă-Pustie (Empty-Belly) and killer of his own wife, is to untie Zahei's vow on quitting to drink, feeding his trustful mind with shameless lies and putting him again on a sinful course. At some point, after the "wedding night" from the salt mine, Zahei says to this one: “Hey, you see, I am blind on the outside. But you are a darkness on the inside as well, you cannot enlighten me. Mind your own business. Let me be in God's hands...' (ibid.: 186). The last one, closer to what he should be, does not have a clear past either. With his apparently unlimited energy sublimated by the treatment suffered in the prison, father Fulga becomes "another man. A serene saint with an elongated face, having a very long grey beard and crippled in both of his legs" (ibid.: 228). As a symbolic creature, he is completed by the blind giant who came to meet him because of the fame which travelled far away as a consequence of his miraculous healings. At some point, it seems like the path into the Light is being opened for both of them. The burning belief will carry them On the Threshold of Miracle. ${ }^{17}$ A mistake will end this path, though. On the other hand, father Fulga is not a good guide either, the blind man's questions making him uneasy on many occasions. ${ }^{18}$ Questioned about the way in which he "sees" the daystar's rays, Zahei

15 "And his nose was pointing out as a vulture's pecker. Hence the nickname of father Gioarsă. He was good at selling the collected junk. He had his skilful flock of women who were selling the goods in other slums, covertly and safely. He used to go in the village empty-handed, crying out loud that he was being robbed and came back with his pockets full of good and needed merchandise. And until evening he had a gipsy girl in his bed" (Voiculescu 2010: 72).

16 One can find a disturbing image related to the way in which some people are taking advantage of the abandoned children in India, who are being blinded intentionally with molten lead and then used for begging, as is to be found in the motion picture named Slumdog Millionaire. The "masters" are making a great profit due to the increased generosity of the common people who are making an analogy with Surdas, one of the greatest Hindi poets and musicians from the $16^{\text {th }}$ century, who was also blind (Slumdog Millionaire. 2008. Directed by: Danny Boyle, Loveleen Tandan, written by: Simon Beaufoy, after a novel by: Vikas Swarup. Pathé Pictures International).

17 A play written in 1934, with a plot reused in a latter story, Sacul cu cartofi (The Sack of Potatoes).

18 '“Isn't it possible, father, that we are the two-headed beast from the Apocalypse?' And he was chilled to the bones ... 'No', father corrected him, 'you are in confusion, Zahei. That beast has only one head and seven horns on it... We don't have on these two stupid heads of ours more than four long ears and no thread of mind underneath them. So, from this part, don't worry'. Sometimes, though, the blind man's thoughts make the priest hesitant. 'Father, isn't it possible', said Zahei, after learning about blind Tobit's story, 'isn't it possible that you are the angel who 
answers: «It is as beautiful as a cherub's eye», used to say happily... 'Do you see him?' 'I can see him well enough...' 'And how do you know about the cherubim's eyes?' 'Well, they are showing themselves to me, sometimes', mysteriously answered the blind, making father Fulga chill..." (ibid.: 229). It seems like the blind has access to visions even more powerful than the penitent father. Besides, the frightful scene of Irmilie's seizure - the epileptic with ominous visions from the second chapter of Voiculescu's novel - actually reveals what it is all about. "Being pushed until he was near the possessed man, Zahei leaned over to him... Irmilie recognized him. 'Run away, God's man', he shouted. 'Don't touch me. What do you want from me? You don't know? My name is legion. It has been a long time since I came out of you..." (ibid.: 190). As Jinga underlines it, "this scene is written according to the gospel regarding the healing of the possessed man from Gadarenes County - a theme which was used by Voiculescu in Midrash style in his short story Demoniacul din Gadara. File dintr-un apocrif' (The Demoniacal Man from Gadarenes. Pages from an Apocrypha) (Jinga, 2001: 57).

Actually, the way in which Voiculescu makes literature is being pointed out by Jinga, as we stated before.

[The text] must function as an icon: meaning that it has to stylize the significant forms of the century on a frame of biblical origin until the stage of a symbol and to offer them as a support, not for meditation but for contemplation. And the forms of the century cannot be brought to the stage of a symbol in other way than through contact, by painting them onto a canvas discretely impregnated with elements already consecrated. (Mastan 2005: 126)

According to the theologian, "Voiculescu believes in the edifying power of literature, not in the magic of the text though, and this is even if, to him, the letter's sacred aura is the result of a deliberated act of 'contamination"” (Jinga, 2001: 61).

It seems like, reaching maturity, Voiculescu abandons his almost Luciferian élan from the poem Prometheus, "the furious zeal" being melted and giving space to

guides me into healing?' (...) «Shut up», the priest reproved him harshly, 'don’t tempt God. The angel would stay on your right and would guide you holding your hand, not like me, perching on your back, as only the devils are standing. And then, Raphael, the angel, guided Tobit's son, who wasn't blind. Do you have a child?"' (Voiculescu 2010: 238). A symbolical interpretation of the numbers which appear in this dialogue (from which one could infer and anticipate the failure of the two half man's endeavour) is elaborated by Bianca Mastan. "Let us lean onto the meanings of the numbers from this fragment as they are seen in the Jewish culture. The number one (one head) represents the number of perfection, as well as the number seven (seven horns). Number two (two heads) is considered to be an imperfect number, being situated between two perfect numbers (one and three), and four (four ears) is composed by adding two and two. Thus, the being which is formed symbiotically is a representation of imperfection by analogy with the numbers of the elements composing it, and the beast of the Apocalypse, in the priest's vision, is the embodiment of perfection" (Mastan 2005: 126). 
resignation, the world's salvation being transferred, again, to Christ's shoulders, with His second arrival. The failure of the world's symbolic rebirth from the end of Voiculescu's novel, pictured through the death of the new priest's child during the service of baptism performed by the old priest who was driven by conceit, reveals the level of decay reached by our humanity. The fact that his mentor cannot reach the height needed for accessing the state of enlightenment, as happened in the case of Seraphim of Sarov and his apprentice, Motovilov (Scrima 1996: 201-202), leads to the desolate image from the end of the novel, where the giant has fallen in a mute state of hopeless prostration, revealing the idea of man's failure without the transcendence's aid, which is Love.

Summarizing, as Constantin Mohanu - "borrowing” without any trace of art from Elena Zaharia-Filipaş' work $-{ }^{19}$ underlines in the foreword of a recent edition of Voiculescu's novel, the author designates to Zahei one "mentor" per chapter, our character being the only one who goes through each section until the end.

The only one who endlessly believed in the possibility of a miracle in order to regain his sight is Zahei. None of the blind man's guides from each of the four chapters of the novel believes in his ideal - they are joining Zahei only for their hidden agendas. One can see that all of them are dying of unnatural causes. Panther, drown in the waters of Buzău River; Caliopi strangled; Boieru, the convict, smashed along with the huge block of salt used as a means to escape from the gaol; father Fulga, the priest, collapsed in front of the forgotten priory's altar when he realized that the gift of priesthood abandoned him. In a world dominated by vice, uncleanness, and human vanity, the innocent Zahei is being guided, one after another, by a clown, a courtesan, a convict, and a priest (...) (Mohanu in Voiculescu 1996: VI)

Thus, not being allowed to have a true guide, Voiculescu's character fails in his initiation - an endeavour towards the Light - because he is not driven by the right motives.

19 Cf. "Let us point out the fact that not even one of Zahei's guides did believe in his ideal of seeing again. Then, that all of them died of unnatural causes: Panteră drown in the waters of Buzău River, Caliopi strangled by the neck, Boeru fallen with the immense globe of salt, and, finally, the priest nullified by his own lack of vocation, as if their guilty intrusion in the innocent blind's life would have asked for retribution. A clown, a courtesan, a convict, and a priest - there are the blind man's guides into a world full of vices and human vanity” (Zaharia-Filipaş 1980: 210). 


\section{Conclusions}

Arriving at the end of our short journey through the world of Voiculescu's novel, seen as an expression of "God's laugh" in the form of Eco's intentio operis, as it was theorized by Kundera on the footsteps of an old Jewish proverb, one could see the fact that the only novel of the Romanian poet and narrator is, indeed - as the longest type of the epic genre - the modern form of keeping and presenting the traditional philosophical and religious beliefs, as it is seen by Salmann. The way in which the author writes on paper his narratives was pointed out by Jinga, the one who observed that Voiculescu's text is being woven on a net of biblical symbols sustaining a pilgrimage in the Oriental style, and not picaresque, as inadequately describes it one of the main Romanian literature's critics. This is because Voiculescu's true theatrum mundi, with a carnivalesque touch, represents only the spot of colour which deceives, feeding only the hungry man's eye of clay and shielding the sight of the one who cannot activate, from ignorance, the eye which sees the things that matter in life, the eye of the heart, according to the fox's advice for the little prince from Saint-Exupery's immortal story. Therefore, Zahei Orbul is a prayer in the true meaning of the word, as it was seen by Culianu, a mute prayer which expresses a scream of a man lost in Marion's distance, which is not being perceived as God's retreat in order to be inhabited by us, on the Son's footsteps, but as immensity, as Maya's veil, where the modern man is lost, being stunned by modernity's sound and light company. The contrast between the carnivalesque world - along with all of its sound and colour inebriation - and the blind's incapacity to perceive it through the sense of sight is a very good idea coming from a words craftsman. It conceals, though, in full sight, a higher level into the text's depth, which bears meaning only when the reader is capable of perceiving the net of symbols mentioned before, symbols which bear witness to the necessity of activating the blind man's "inner teacher" in order to find his path into the Light. Voiculescu's character fails, even if he has all the cards for succeeding, because he is incapable of choosing the type of light he is seeking, the author not allowing him to have a proper spiritual guidance in this endeavour.

\section{Limitations and further research}

Keeping in mind the fact that this paper represents the introductory part to a larger project, ${ }^{20}$ regarding the net of Christian symbols emerging from the core of Voiculescu's novel as opposed to the apparent absence of Love from its surface, one could find our study hard to follow.

20 From which we have already published Şarpele, simbol creştin în romanul lui V. Voiculescu (The Serpent, a Christian Symbol in V. Voiculescu's Novel). 
On top of that, the emphasis on the meaning of beyond from the prefix trans- in transdisciplinarity, used as a method in order to grasp some of the "visible" effects of the "hidden third", could also be an impediment for those who are looking for objective results only. As mentioned before, our method is the road revealing itself under our feet, as we put one step before the other, starting from a "place" in the "distance" (Marion), on the threshold of an icon emerging from Voiculescu's novel, seeking the presence of God, who invites the reader to inhabit it, on the footsteps of Christ.

Another aspect which could make this study difficult to read is the fact that it was thought and written as an essay, initially, and adapted to better fit the requirements of an academic paper. Therefore, it might not be easy to clearly see the objective of the research in this paper, many aspects of the discussed subjects being implied. Nonetheless, in the larger picture of our research, they are visible enough.

\section{References}

Anania, Valeriu. 1995. Din spumele mării [Out of the sea foam]. Cluj-Napoca: Dacia. Crainic, Nichifor. 1929. Sensul tradiției [The meaning of tradition]. Gândirea 9(1-2): 1-11.

Culianu, Ioan Petru. 2000. Studii româneşti I [Romanian studies I]. Bucharest: Nemira.

Culler, Jonathan-Rorty, Richard-Brooke-Rose, Christine. 1992. Interpretation and overinterpretation. In: Eco, Umberto-Collini, Stefan (eds.), Tanner lectures in human values. Cambridge: University Press.

Eliade, Mircea. 1961. The sacred and the profane. The nature of religion. Transl. by Willard. R. Trask. New York: Harper Torch Books.

Fundoianu, Barbu. 1980. Imagini şi cărți [Images and books]. Bucharest: Minerva.

Jinga, Constantin. 2001. Biblia şi sacrul în literatură [The Bible and the sacred in literature]. Timişoara: Editura Universității de Vest, colecția episteme [2].

Kundera, Milan. 2008. Arta romanului. [The art of the novel]. Transl. by Simona Cioculescu. Bucharest: Humanitas.

Marion, Jean-Luc. 2007. Idolul şi distanța. [The idol and the distance]. Transl. by Daniela Pălăşan-Tinca Prunea-Bretonnet. Bucharest: Humanitas.

Mastan, Bianca. 2005. Elemente simbolice în romanul Zahei Orbul, de Vasile Voiculescu [Symbolic elements in the novel "Zahei the Blind" by Vasile Voiculescu]. Studia Universitatis Babeş-Bolyai, Theologia Catholica 50(2): 119128.

Nicolesco, Basarab. 2006. Transdisciplinarity-Past, present and future. In: Haverkort, Bertus-Reijntjes, Coen (eds.). Moving worldviews - Reshaping sciences, policies and practices for endogenous sustainable development. COMPAS Editions. 
Salmann, Elmar. 2010. Romanul ca model pentru teologie [The novel as a model for theology]. Vatra 37(5-6): 180-184.

Scrima, Andre. 1996. Timpul Rugului Aprins. Maestrul spiritual în tradiția răsăriteană [The time of the burning bush. The spiritual master in the Eastern tradition]. Bucharest: Humanitas.

Sorescu, Roxana. Tertium non datur vs Capul de zimbru [Tertium non datur vs. The bison's head]. https://www.observatorcultural.ro/articol/tertium-non-daturversus-capul-de-zimbru-2/ (downloaded on: 04.01.2020).

Steiner, Rudolf. 1961. Christianity as mystical fact and the mysteries of antiquity. New York: Blauvelt.

Steinhardt, Nicolae. 1994. Dăruind vei dobândi [Giving is gaining]. Cluj-Napoca: Dacia.

Suciu, Sorin-Gheorghe. 2013. Şarpele, simbol creştin în romanul lui V. Voiculescu [The serpent, a Christian symbol in V. Voiculescu's novel]. In: Iulian Boldea (ed.), Studies on literature, discourse and multicultural dialogue. Tg.-Mureş: Arhipelag XXI. 1251-1262.

Voiculescu, Vasile. 1996. Zahei Orbul [Zahei the blind]. Bucharest: 100+1 Gramar. 2003. Opera literară. Proza [Literary oeuvre. Prose]. Bucharest: Cartex 2000. 2010. Zahei Orbul [Zahei the blind]. Bucharest: Art.

Zaharia-Filipaş, Elena. 1980. Introducere în opera lui Vasile Voiculescu [An introduction to Vasile Voiculescu's oeuvre]. Bucharest: Minerva. 